\title{
HTR2C wt Allele
}

National Cancer Institute

\section{Source}

National Cancer Institute. HTR2C wt Allele. NCI Thesaurus. Code C115017.

Human HTR2C wild-type allele is located in the vicinity of Xq23 and is approximately 326 $\mathrm{kb}$ in length. This allele, which encodes 5-hydroxytryptamine receptor $2 \mathrm{C}$ protein, plays a role in serotonin binding and signaling. This gene undergoes RNA deamination at sites designated A, B, C-prime, E, C, and D; RNA editing at sites C, D and C-prime may be associated with depression. 